\title{
Effect of Plant Density and Nutrient Management on Yield and Economics of Maize (Zea mays L.) Hybrids
}

\author{
S. Biswas ${ }^{1 \ngtr(0)}$, S. Debnath ${ }^{1}$ and A. Saha² \\ ${ }^{1}$ Assistant Professor, AICRP on Maize, Directorate of Research, BCKV, Kalyani, Nadia, West Bengal (741 235), India \\ ${ }^{2}$ College of Agriculture, Lembucherra, West Tripura, Tripura (799 210), India
}

Open Access

Corresponding $邓$ sonali.saha80@gmail.com

0000-0001-7911-7102

\section{ABSTRACT}

$\mathrm{T}$ he field experiments wereconducted during kharif season (June to October)of both 2016 and 2017 to determine the effect of plant density and nutrient management on yield and economics of maize hybrids at Kalyani AB Block seed farm situated

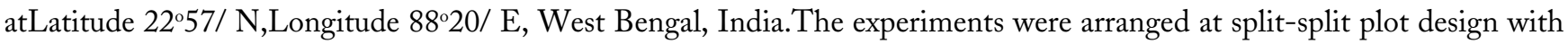
three replication, two maize hybrids (Pioneer 3077 and Kaveri 50) were in main plot, two plant density $\left(60 \times 20 \mathrm{~cm}^{2}\right.$ and $50 \times 20$ $\mathrm{cm}^{2}$ ) were in sub plot and three nutrient levels (Recommended Dose of Fertilizer i.e. 120:60:60 N:P $\mathrm{O}_{5}: \mathrm{K}_{2} \mathrm{O} \mathrm{kg}$ ha ${ }^{-1}$, Soil test crop response i.e. 170:60:68 N:P $\mathrm{P}_{2}: \mathrm{K}_{2} \mathrm{O} \mathrm{kg} \mathrm{ha}{ }^{-1}$ and Site Specific nutrient management i.e. 130:44:66 $: \mathrm{P}_{2} \mathrm{O}_{5}: \mathrm{K}_{2} \mathrm{O} \mathrm{kg} \mathrm{ha}{ }^{-1}$ ) were in sub-sub plot. Result indicated that maize hybrid pioneer 3077 recorded higher grain yield, stover yield and net return and B:C ratio of maize than other hybrid. Higher plant density $50 \times 20 \mathrm{~cm}^{2}$ produced significantly higher yield and economics of maize than lower plant density. Among the nutrient management, Soil Test Crop Response (STCR) was found significantly superior than others and recorded highest grain yield, stover yield and economics of maize. Soil Test Crop Response based nutrient management increased in grain yield was $24.26 \%$ over Recommended Dose of Fertilizer (RDF) and $12.29 \%$ over Site Specific nutrient management (SSNM).

KEYWORDS: Grain yield, nutrient management, maize hybrids, plant density

Citation (VANCOUVER): Biswas et al., Effect of Plant Density and Nutrient Management on Yield and Economics of Maize (Zea mays L.) Hybrids. International Journal of Bio-resource and Stress Management, 2022; 13(1), 37-44. HTTPS://DOI.ORG/10.23910/1.2022.2243b.

Copyright: (C) 2022 Biswas et al. This is an open access article that permits unrestricted use, distribution and reproduction in any medium after the author(s) and source are credited.

Data Availability Statement: Legal restrictions are imposed on the public sharing of raw data. However, authors have full right to transfer or share the data in raw form upon request subject to either meeting the conditions of the original consents and the original research study. Further, access of data needs to meet whether the user complies with the ethical and legal obligations as data controllers to allow for secondary use of the data outside of the original study.

Conflict of interests: The authors have declared that no conflict of interest exists.

RECEIVED on $02^{\text {nd }}$ April 2021 RECEIVED in revised form on $29^{\text {th }}$ November 2021 ACCEPTED in final form on $15^{\text {th }}$ January 2022 PUBLISHED on $31^{\text {st }}$ January 2022 


\section{INTRODUCTION}

$\mathrm{M}$ aize (Zea mays L.) is the World's leading crop and is cultivated as cereal grain in India that contributed to nearly $9 \%$ of the national food security. Maize (Zea mays L.) is the third most important crop after rice and wheat in India. The demand for maize grain is increasing due to rapid growth in poultry and animal husbandry feed sector (Shyam et al., 2021 and Singh et al., 2018) and production is increasing owing to multifarious usage. (Yadav et al., 2016). The productivity of maize in India is still very low $\left(2689 \mathrm{~kg} \mathrm{ha}^{-1}\right)$, as compared to the world $\left(5500 \mathrm{~kg} \mathrm{ha}^{-1}\right)$, showing a large gap between potential productivity and actual productivity. (Singh et al., 2020). Among various factors responsible for low crop yield, plant population in the field and selection of unsuitable cultivars are of prime importance (Biswas et al., 2020, Yao et al., 2016 and Battaglia et al., 2019). Xu et al., 2017 stated that as planting density increased from 67,500 to 90,000 plants $\mathrm{ha}^{-1}$ grain yield was significantly increased by $7 \%$. Thus, maintenance of optimum plant density play a vital role in nutrient absorption and partition in different plant parts (Hang et al., 2018 and Zhai et al., 2018). Planting density has proven to be a very effective agronomic strategy to improve maize grain yield (Shi et al., 2016). Newer hybrids were more tolerant to high plant population than the older hybrids. Therefore, the recently released hybrids were more adapted to biotic stress. High yielding maize hybrids, with very high biomass production, extracts higher amounts of mineralnutrients from the soil than other major cereals like rice orwheat. Nutrient requirement of maize varies from field tofield due to high variability in soil fertility across farmer's fields and also varies with the yield potential of hybrids (Hargilas et al., 2017). There is a good genotype interaction of maize in varied ecology and management practices (Kumar et al., 2016). Nitrogen, $\mathrm{P}$ and $\mathrm{K}$ are very important nutrients for maize crop in order to harvest high yield in kharif season (Singh et al., 2017). Maize being an exhaustive crop requires a large quantity of nutrients during different growth periods. The yield improvements were realized by adopting more efficient technologies and improved $\mathrm{N}$ fertilizer management (Zhang et al., 2018). The blanket fertilizer recommendations do not account the change in ecology and the genetic potential of the genotype (Parihar et al., 2017). Several approaches used for fertilizer recommendation in maize, like precision nutrient management through spatial variability assessment and variable rate technologies, site specific nutrient management (SSNM), soil test crop response (STCR), nutrient expert (NE) and recommended dose of fertilizer etc. Among several soil test-based fertilizer application techniques, site specific nutrient management (SSNM) and soil test crop response
(STCR) are plant need based approaches with specific yield target. (Singh et al., 2017 and Neha et al., 2018). To address this complex problem of nutrient mining and deterioration of soil health, Site Specific Nutrient Management (SSNM) is one of the way of increasing the crops productivity and sustains the soil health through ensuring adequate supply of the nutrients specific to the crop and soil (Singh et al., 2016). The SSNM and STCR approaches not only aim to reduce or increase fertilizer use and also cost effective tools for supplying crop nutrient as and when needed to achieve higher yield, besides this they also aims to increase system nutrient use efficiency (Shreenivas et al., 2017 and Joshi and Chandrasekhar, 2017). Therefore, it is imperative to optimize fertilizer management during the maize growth period, which can not only reduce $\mathrm{N}$ input but also improve grain yield and environmental sustainability (Young et al., 2018). Increasing productivity and production are essential to meet the food requirement of the burgeoning population. This is achieved through its unique balance of nutrients and clay minerals, which also increases microbial activity and builds long term soil fertility (Ranva et al., 2019). Therefore, a reasonable increase of planting density and supplying adequate $\mathrm{N}$ application are important agronomic practices to increase maize grain yield (Du et al., 2021 and Chen et al., 2018). For increasing productivity, better nutrient management systems are needed to complement genetic improvement efforts (Ray et al., 2018). Since there are differential response to applied nutrients and crop geometry, it is imperative to evaluate performance of hybrids for their efficiency and response to nutrients and intra-row spacing. It was, therefore, considered worthwhile to undertake this present investigation in order to evaluate the effect of plant density and nutrient levels on yield and economics of maize hybrids during kharif season.

\section{MATERIALS AND METHODS}

\subsection{Experimental site description}

The experiments were conducted at Kalyani, AB Block seed farm (Latitude 22 $57 / \mathrm{N}$, Longitude $88^{\circ} 20 / \mathrm{E}$ and at of $9.75 \mathrm{~m}$ above sea level), West Bengal, India during the kharif season (June to October) of 2016 and 2017, respectively. The soil of the experimental site was sandy clay loam having $\mathrm{pH}$ neutral in reaction with medium in organic carbon $(0.52 \%)$ and available nitrogen $\left(269 \mathrm{~kg} \mathrm{ha}^{-}\right.$ $\left.{ }^{1}\right)$, high in available phosphorus $\left(34 \mathrm{~kg} \mathrm{ha}^{-1}\right)$ and medium in available potassium $\left(209 \mathrm{~kg} \mathrm{ha}^{-1}\right)$. The study area falls under sub-humid tropical climate. Kalyani usually receives an average annual rainfall of $1600 \mathrm{~mm}$ out of which 1300 $\mathrm{mm}$ occurs during monsoon. The maximum and minimum temperature was 24.1 and $34.2^{\circ} \mathrm{C}$ during 2016 and 23.8 and $35.1^{\circ} \mathrm{C}$ during 2017 , respectively. 


\subsection{Agronomic practices}

Before sowing of the crop, the field was well prepared by ploughing twice with tractor followed by one planking. Well decomposed farm yard manure at the rate of $12 \mathrm{t} \mathrm{ha}^{-1}$ was applied before last ploughing. Maize seeds were sown in the $2^{\text {nd }}$ week of June and harvested in the middle of October in both the years respectively. As per the treatment, nitrogen was applied in the form of urea (46\%) in three splits, viz., $25,50,25 \%$ as basal, 25 and 45 days after sowing. The entire dose of phosphorus in the form of single super phosphate (16\%) and potassium in the form of muriate of potash (60\%) were applied as basal. Weed, pests and diseases control were done in a timely manner.

\subsection{Experimental design and treatments}

The experiment was arranged at split-split plot design with three replication, two maize hybrids (pioneer 3077 and Kaveri 50) were in main plot, two plant density $(60 \times 20$ $\mathrm{cm}^{2}$ and $50 \times 20 \mathrm{~cm}^{2}$ were in sub-plot and three nutrient levels (RDF i.e. 120:60:60 N: $\mathrm{P}_{2} \mathrm{O}_{5}: \mathrm{K}_{2} \mathrm{O} \mathrm{kg} \mathrm{ha} \mathrm{k}^{-1}$, STCR i.e. 170:60:68 N:P $\mathrm{O}_{5}: \mathrm{K}_{2} \mathrm{O} \mathrm{kg} \mathrm{ha}{ }^{-1}$ and SSNM i.e. 130:44:66 $\mathrm{N}: \mathrm{P}_{2} \mathrm{O}_{5}: \mathrm{K}_{2} \mathrm{O} \mathrm{kg} \mathrm{ha}{ }^{-1}$ ) were in sub-sub plot.In STCR (Soil Test Crop Response) based nutrient recommendations, the basic data viz., nutrient requirement (NR) $\left(\mathrm{kg} \mathrm{t}^{-1}\right)$, and percent contribution from the soil available nutrients [CS (\%)] and the percent contribution from the applied fertilizer nutrients [CF (\%)] were transferred into workable adjustment equation. Fertilizer dose $=[$ Nutrient requirement $\left(\mathrm{kg} \mathrm{t}^{-1}\right)$ of grain]/ [CF (\%)] 100xT ( $\left.\mathrm{t} \mathrm{ha}^{-1}\right)-$ $[\mathrm{CS}(\%)] /[\mathrm{CF}(\%)] \times\left[\right.$ soil test value $\left.\left(\mathrm{kg} \mathrm{ha}^{-1}\right)\right]$. Where $\mathrm{T}$ is targeted yield $\left(\mathrm{t} \mathrm{ha}^{-1}\right)$.

For site specific nutrient management (SSNM), the nutrient status of the soil, previous crops etc. were used for computing the nutrient requirement by using IPNI (International Plant Nutrition Institute) Nutrient Expert for hybrid maize software. Nutrient Expert ${ }^{\circledR}$ is an interactive, computerbased decision-support tool that enables smallholder farmers to rapidly implement SSNM in their individual fields with or without soil test data. The software estimates the attainable yield for a farmer's field based on the growing conditions determines the nutrient balance in the cropping system based on yield and fertilizer/manure applied in the previous crop and combines such information with expected $\mathrm{N}$, phosphorus $(\mathrm{P})$ and potassium $(\mathrm{K})$ response in target fields to generate location-specific nutrient recommendations. The software also does a simple profit analysis comparing costs and benefits between farmers' current practice and recommended alternative practices. The algorithm for calculating fertilizer requirements was developed from on-farm research data and validated over 5 years of testing.

\subsection{Observation and statistical analysis}

Biometric observations likes plant height, dry matter accumulation, cob length, cob girth, rows $\mathrm{cob}^{-1}$, seeds $\operatorname{cob}^{-1}$, 100 seed weight, grain yield and stover yield were recorded at harvest. The harvest index, economics, benefit: cost ratio of crop were calculated on the basis of the local market prices of the inputs and outputs. The collected pooled data of the two seasons were statistically analysed according to the analysis of variance (ANOVA) by using MSTAT-C computer.

\section{RESULTS AND DISCUSSION}

$\mathrm{D}_{1}$ etails of the observation had been mentioned in Table 1 and 2 . The results had been described under different sections as below.

\subsection{Growth parameters}

\subsubsection{Effect of maize bybrids}

The plant height of maize was significantly influenced by maize hybrids. Among the hybrids, the tallest plant height $(205.9 \mathrm{~cm})$ was recorded under Pioneer 30R77at harvesting stage. Lowest plant height $(191.80 \mathrm{~cm})$ was reported by hybrids Kaveri 50 . The differential growth with respect to plant height observed between the varieties might be attributed to differences in genetic characteristics of the individual varieties, including the height of the varieties. Maize hybrids Pioneer 30R77 produced highest dry matter accumulation $\left(1135.00 \mathrm{~g} \mathrm{~m}^{-2}\right)$ at harvest than other maize hybrids Kaveri 50. Genotypic character of different genotypes might have attributed difference in plant height and dry matter accumulation in this investigation. Similar findings were observed by Wijewardana et al. (2019), Coelho et al., 2020 and Ke and Ma, 2021. Growth parameters are also strongly influenced by environmental conditions during stem elongation and other growth stages, although there is considerable varietal variation in this characteristic. (Khedwal et al., 2018).

\subsubsection{Effect of planting density}

The plant density had significant effect on plant height and dry matter accumulation of crop. Plant height was the highest $(204.8 \mathrm{~cm})$ with higher plant density owing to inter-plant competition for light. The significant increase in plant height with decreased intra row spacing seems to be the resultant of competition for light. The result is in close accordance with findings Al-Naggar et al., 2021 and Bernhard and Below 2020. Dry matter accumulation was also higher $\left(1105.33 \mathrm{~g} \mathrm{~m}^{2}\right)$ at higher planting density than lower planting density. Under high plant density, more number of plants per unit area was responsible for higher dry matter accumulation. Naik et al., 2019 reported that dry matter accumulation was significantly influenced by different planting density and higher plant density increased the dry matter accumulation at different growth stages. 
Table 1: Effect of planting densities and nutrient management on growth and yield attributing characters of maize

\begin{tabular}{|c|c|c|c|c|c|c|c|}
\hline Treatments & $\begin{array}{l}\text { Plant height } \\
\text { at harvest } \\
(\mathrm{cm})\end{array}$ & $\begin{array}{c}\text { Dry matter } \\
\text { accumulation } g \\
\mathrm{~m}^{-2} \text { at harvest }\end{array}$ & $\begin{array}{l}\text { Cob } \\
\text { length } \\
(\mathrm{cm})\end{array}$ & $\begin{array}{c}\text { Cob } \\
\text { diameter } \\
(\mathrm{cm})\end{array}$ & $\begin{array}{l}\text { No. of } \\
\text { rows } \\
\operatorname{cob}^{-1}\end{array}$ & $\begin{array}{l}\text { No. } \\
\text { grains } \\
\text { cob }^{-1}\end{array}$ & $\begin{array}{c}100 \text { seed } \\
\text { weight } \\
(\mathrm{g})\end{array}$ \\
\hline \multicolumn{8}{|l|}{ Hybrids } \\
\hline Pioneer-30R77 & 205.9 & 1135.00 & 18.7 & 15.6 & 13.6 & 34.1 & 32.4 \\
\hline Kaveri 50 & 191.80 & 1099.00 & 16.6 & 14.5 & 13.2 & 31.1 & 28.4 \\
\hline $\mathrm{SEm} \pm$ & 4.19 & 20.42 & & 0.40 & 0.27 & 0.89 & 1.17 \\
\hline $\mathrm{CD}(p=0.05)$ & 12.7 & 61.25 & NS & NS & NS & NS & 3.5 \\
\hline \multicolumn{8}{|l|}{ Planting density } \\
\hline $60 \times 20 \mathrm{~cm}^{2}$ & 190.9 & 1035.67 & 16.6 & 14.2 & 12.8 & 31.5 & 29.3 \\
\hline $50 \times 20 \mathrm{~cm}^{2}$ & 204.8 & 1105.33 & 18.7 & 15.9 & 14.0 & 33.7 & 31.6 \\
\hline $\mathrm{SEm} \pm$ & 4.09 & 19.72 & & 0.42 & 0.32 & 0.74 & 0.90 \\
\hline $\mathrm{CD}(p=0.05)$ & 12.01 & 59.25 & NS & 1.3 & 1.0 & 2.2 & NS \\
\hline \multicolumn{8}{|c|}{ Nutrient management (NPK kg ha-1) } \\
\hline Recommend dose of fertilizer & 188.4 & 1022.20 & 16.7 & 14.2 & 12.8 & 30.3 & 27.5 \\
\hline Soil test crop response & 195.4 & 1202.50 & 18.6 & 15.9 & 14.1 & 34.7 & 33.2 \\
\hline Site specific nutrient management & 212.7 & 1158.45 & 17.7 & 15.0 & 13.3 & 32.8 & 30.7 \\
\hline $\mathrm{SEm} \pm$ & 4.21 & 19.62 & & 0.31 & 0.26 & 1.06 & 0.77 \\
\hline $\mathrm{CD}(p=0.05)$ & 12.7 & 58.90 & NS & 0.90 & 0.80 & 3.20 & 2.30 \\
\hline
\end{tabular}

Table 2: Effect of planting densities and nutrient management on yield and economics of maize

\begin{tabular}{lcccccc}
\hline Treatments & $\begin{array}{c}\text { Grain yield } \\
\left(\mathrm{Kg} \mathrm{ha}^{-1}\right)\end{array}$ & $\begin{array}{c}\text { Stover yield } \\
\left(\mathrm{Kg} \mathrm{ha}^{-1}\right)\end{array}$ & $\begin{array}{c}\text { Harvest } \\
\text { index }(\%)\end{array}$ & $\begin{array}{c}\text { Gross return } \\
\left(₹ \mathrm{ha}^{-1}\right)\end{array}$ & $\begin{array}{c}\text { Net return } \\
\left(₹ \mathrm{ha}^{-1}\right)\end{array}$ & $\begin{array}{c}\text { B:C } \\
\text { ratio }\end{array}$ \\
\hline Hybrids & & & & & & \\
Pioneer-30R77 & 10201.00 & 10448 & 39.77 & 142308.50 & 92769.20 & 3.025 \\
Kaveri 50 & 8869.00 & 10338.90 & 41.40 & 127210.50 & 76679.40 & 2.65 \\
SEm \pm & 184.14 & 38.6 & 0.012 & 5616.50 & 4625.50 & 0.082 \\
$\mathrm{CD}(p=0.05)$ & 552.50 & 115.20 & $\mathrm{NS}$ & 16850.25 & 13877.00 & 0.248 \\
Planting density & & & & & & \\
\hline $60 \times 20 \mathrm{~cm}^{2}$ & 8070.00 & 9764.50 & 40.21 & 116119.00 & 65580.40 & 2.482 \\
$50 \times 20 \mathrm{~cm}^{2}$ & 10828.50 & 12280.45 & 40.60 & 154390.40 & 103852.50 & 3.247 \\
SEm \pm & 192.40 & 182.70 & 0.07 & 5081.50 & 4049.80 & 0.080 \\
CD $(p=0.05)$ & 577.30 & 548.25 & $\mathrm{NS}$ & 15245.00 & 12149.50 & 0.245 \\
Nutrient management $\left(\mathrm{NPK} \mathrm{kg} \mathrm{ha}{ }^{-1}\right)$ & & & & & & 2.474 \\
\hline Recommend dose of fertilizer & 8234.25 & 9702.50 & 40.60 & 117900.40 & 67409 & 2.058 \\
Soil test crop response & 10872.50 & 12292.40 & 40.72 & 152200.50 & 100971 & 3.058 \\
Site specific nutrient management & 9536.80 & 11075.80 & 40.07 & 136670.40 & 85780.58 & 3.00 \\
SEm \pm & 142.82 & 154.20 & 0.14 & 5852.50 & 3794.20 & 0.03 \\
CD $(p=0.05)$ & 428.45 & 462.80 & 0.41 & 17560.50 & 11382.80 & 0.12 \\
\hline
\end{tabular}

1US $\$=₹ 67.8286$ INR in 2016 and 1 US $\$=₹$ 65.0966 INR in 2017 


\subsubsection{Effect of nutrient management}

Different nutrient management significantly influenced the plant height and dry matter accumulation of crop. Maximum plant height $(195.4 \mathrm{~cm})$ and dry matter accumulation $\left(1202.50 \mathrm{~g} \mathrm{~m}^{-2}\right)$ was recorded under STCR based nutrient management treatment compared than others. Lowest plant height $(188.4 \mathrm{~cm})$ and dry matter accumulation $\left(1022.20 \mathrm{~g} \mathrm{~m}^{-2}\right)$ was recorded under RDF based nutrient management treatment. Singh et al., 2021 reported that maize growth parameters like plant height and dry matter accumulation were higher by STCR based nutrient management. Shreenivas et al., 2017 reported significantly higher plant height and number of branches, respectively was observed in residual effect of nutrients through SSNM approach targeted yield of $8.0 \mathrm{t} \mathrm{ha}^{-1}(36.55$ $\mathrm{cm}$ and 29.57) and by STCR approach targeted yield of 8.0 $\mathrm{t} \mathrm{ha}^{-1}(36.20 \mathrm{~cm}$ and 28.87$)$ as compared to other treatments. Shyam et al., 2021 stated that plant height and other growth parameters influenced by precision nutrient management in maize.

\subsection{Yield attributing characters}

\subsubsection{Effect of maize hybrids}

Pooled data of the experiment showed that yield attributing character like 100 seed weight was significantly influenced by maize hybrids. Effect of maize hybrids on cob length, cob girth, number of rows per cob and number of grains per rows were non-significant. Maize hybrid Pioneer-30R77 recorded maximum 100 seed weight $(32.4 \mathrm{~g})$ than Kaveri 50 hybrid. The variation in yield characters between both the varieties might be due to genetical variation in the varieties. (Singh., 2016, Khedwal et al., 2018 and Coelho et al., 2020).

\subsubsection{Effect of planting density}

Pooled data showed that planting density significantly influenced the cob girth, number of rows per cob and 100 seed weight but cob length and number of grains per row were non-significant. Higher planting density recorded higher cob girth $(15.9 \mathrm{~cm})$, number of rows per cob (14.0) and 100 seed weight $(32.4 \mathrm{~g})$ and it was comparable with $60 \times 20 \mathrm{~cm}^{2}$ planting density. Increased planting density produced a significant $23 \%$ increase of average ear number; kernel number and other yield components. (Xu et al., 2017 and Al-Naggar et al., 2021)

\subsubsection{Effect of nutrient management}

Different nutrient management significantly influenced different yield parameters except cob length. STCR based nutrient management produced significantly higher cob girth $(15.9 \mathrm{~cm})$, number of rows per cob (14.1), number of grains per row (34.7) and 100 seed weight (33.2 g) which were statically at par with SSNM based nutrient management (Singh et al., 2021). Lowest cob diameter
$(14.2 \mathrm{~cm})$, number of rows per cob (12.8), number of grains row $^{-1}$ (30.3) and 100 seed weight (27.5 g) were recorded in plot receiving recommended dose of fertilizer. Shreenivas et al., 2017 reported that higher yield attributes were obtained with the nutrient application through targeted yield approach. (STCR based). Enhanced yield attributes under precision nutrient management resulted in enhanced seed yield. There was higher nutrient uptake, and partitioning of the NPK and other nutrients and which accelerated the growth and yield attributes. (Shyam et al., 2020)

\subsection{Yield}

\subsubsection{Effect of maize bybrids}

Pooled data of experiment showed that maize hybrids were significantly influenced grain yield and stover yield of crop. Among the maize hybrids, Pioneer- 30R77 produced higher grain yield $\left(10,201 \mathrm{~kg} \mathrm{ha}^{-1}\right)$ and stover yield (10,448.45 $\mathrm{kg} \mathrm{ha-1})$. This might be due to better vegetative and reproductive growth of hybrids Pioneer 30R77 contributed to better dry matter accumulation and yield attributing parameters at the same time grain and stover yield of maize. The increase in grain yield could be attributed to the higher yield attributing parameters in Pioneer-30R77. The variation in yields between both the varieties might be due to genetical variation in the varieties. Singh., 2016, Khedwal et al., 2018 and Coelho et al., 2020 reported the similar findings.

\subsubsection{Effect of planting density}

Among the planting density, higher density of planting $\left(50 \times 20 \mathrm{~cm}^{2}\right)$ recorded significantly higher grain yield $(10$, $\left.828.50 \mathrm{~kg} \mathrm{ha}^{-1}\right)$ and stover yield $\left(12,280.45 \mathrm{~kg} \mathrm{ha}^{-1}\right)$ of maize than the lower planting density $\left(60 \times 20 \mathrm{~cm}^{2}\right)$. Light interception was increased with increased plant density, under high plant density increased plant heights as well as light interception. At high density vegetative growth of maize was extended, more number of leaves per plant were produced that increased light interception at the high density, as a result more assimilates were produced by maize crop that increased plant heights as well as light interception which ultimately lead to higher grain yields at high density planting than at low plant density. At low plant density, there in adequate number of plants and therefore ears, that was concluded limits grain yield. Al-Naggar et al., 2021 reported that increasing planting density from 47,600 to $71,400,95,200$ and 119,000 caused a significant increase in grain yield/ha. As planting density increased from 67,500 to 90,000 plants ha ${ }^{-1}$, grain yield was significantly increased by $7 \%$ (from 9,556.5 to $10,184.5 \mathrm{~kg} \mathrm{ha}^{-1}$ ) across years. (Xu et al., 2017). Yu et al., 2019 stated that the increase of planting density from 75,000 plants ha ${ }^{-1}$ to 90,000 plants ha ${ }^{-1}$, yields of high-yielding spring maize varieties improved. Bernhard and Below 2020 reported that narrower row spacings helped 
mitigate crowding stress at greater plant populations by promoting phenotypic changes that consequently led to greater yield. Higher productivity was observed in the high density treatments. (Du et al., 2021)

\subsubsection{Effect of nutrient management}

The significantly higher grain and stover yield of maize was observed in STCR based nutrient management, followed by SSNM approach. This may be due to increased uptake of nitrogen, phosphorus and potassium being part of essential nutrients, required for the production of meristematic tissues and physiological activities of leaves, roots, shoots etc. leading to an efficient translocation of water and nutrients. These physiological activities increased the nutrient uptake which resulted in higher total dry matter production and ultimate the yield of crops. These findings are accordance with experimental results of Yadav and Kumar (2018). Shabnam et al., 2017 stated that STCR based nutrients application in treatment for target yield of $40 \mathrm{q} \mathrm{ha}^{-1}$ with and without FYM resulted in the significantly better productivity of maize $\left(3.76 \mathrm{t} \mathrm{ha}^{-1}\right.$ and $\left.3.67 \mathrm{t} \mathrm{ha}^{-1}\right)$, as compared to conventional treatments. Also the highest B: C ratio (2.30) was recorded under STCR (non-IPNS) approach based target yield treatment for 40 $\mathrm{q} \mathrm{ha}^{-1}$. Shreenivas et al., 2017 reported that the grain yield of maize was recorded higher $\left(8.62 \mathrm{tha}^{-1}\right)$ with treatment receiving SSNM approach targeted yield of $8.0 \mathrm{t} \mathrm{ha}^{-1}$ as compared to absolute control $\left(2.91 \mathrm{tha}^{-1}\right)$, farmers practice $\left(4.74 \mathrm{tha}^{-1}\right)$, state recommendation $\left(5.82 \mathrm{tha}^{-1}\right)$ and soil test laboratory (STL) method $\left(6.25 \mathrm{t} \mathrm{ha}^{-1}\right)$ and it was found at par with STCR approach targeted yield of $8.0 \mathrm{t} \mathrm{ha}^{-1}$ (8.37 $\left.\mathrm{t} \mathrm{ha} \mathrm{h}^{-1}\right)$.The STCR-based nutrient application increased grain yield by $5.7 \%$,respectively over balanced fertilization (recommended doses of NPKZn) (Jhosi et al., 2016). Singh et al., 2021 stated that the STCR-targeted yield approach improved the yield of maize. The increased yield under the STCR approach, with and without FYM, might have been due to the balanced application of fertilizers, as per the soil test, and the crop demand for growth and development. Enhanced yield attributes under precision nutrient management resulted in enhanced seed yield of maize. (Shyam et al., 2020)

\subsection{Harvest index (\%)}

\subsubsection{Effect of maize bybrids}

No significant differences were found in harvest index of maize influenced by hybrids.

\subsubsection{Effect of planting density}

Harvest index was not significantly varied by different plant densities.

\subsubsection{Effect of nutrient management}

The harvest index of maize was significantly varied by different nutrient management. The highest harvest index (40.72\%) was obtained in treatment receiving STCR based nutrient management. The lowest harvest index was notice in treatment receiving recommended dose of fertilizer. Singh et al., 2021 reported that the highest harvest index was recordedin STCR based treatment (44.30\%), which differed significantly from other. Higher dry matter partitioning to grain might be the reason for the higher harvest index under STCR based treatment.

\subsection{Economies}

\subsubsection{Effect of maize bybrids}

Maize hybrids recorded significant influence on gross return, net return and $\mathrm{B}$ : $\mathrm{C}$ ratio of maize. Among the hybrids, Pioneer-30R77 showed maximum gross return (₹ 1 , 42,308.50 ha $\mathrm{ha}^{-1}$ ), net return (₹ 92,769.20 ha $\mathrm{h}^{-1}$ ) and maximum $\mathrm{B}$ : C ratio (3.025) of maize. While minimum gross return (₹ 1 , $27,210.50 \mathrm{ha}^{-1}$ ), net return (₹ 76, 679.40) $\mathrm{ha}^{-1}$ and B: C ratios (2.65) were recorded under Kaveri 50 hybrids. This might be due to the fact that hybrids Pioneer-30R77 having greater potential to produce more grain and stover yield resulting in greater return. The variations in net income between hybrids might due to variation in grain and stover yield. (Khedwal et al., 2018 ). The B:C ratio was also noted in similar manner under both the hybrids. (Singh et al., 2018)

\subsubsection{Effect of planting density}

Two years of the experiment data showed that planting density $50 \times 20 \mathrm{~cm}^{2}$ recorded highest gross return (₹ 1,54,390.40 ha-1), net return (₹ 1,03,852.50 ha- ${ }^{-1}$ ) and B:C ratio (3.247) of maize. The difference in gross return, net return and $\mathrm{B}: \mathrm{C}$ ratio might be due to yield variation between the plant densities. Similar findings were also reported by Singh et al., 2016.

\subsubsection{Effect of nutrient management}

The results of the experiment indicated that the higher gross return ( ₹ 1, 52,200.50 ha-1), net return ( ₹ 1,00,971 $\mathrm{ha}^{-1}$ ) were recorded in STCR based nutrient management. The highest B:C ratio was noticed in STCR based nutrient management which was statistically at with SSNM based nutrient management. (Singh et al., 2021). The lower gross return, net return and $\mathrm{B}: \mathrm{C}$ ratio was found in the treatments receiving RDF (Recommended Dose of Fertilizer). Consistently higher gross returnswere realized during 2012 and 2013, respectively, in balanced application of NPKZn based on STCR approach to maize, which was significantly superior to recommended doses of nutrient. (Joshi et al., 2016, Shyam et al., 2020 and Shreenivas et al., 2017).

\section{CONCLUSION}

$\mathrm{T}$ he maize hybrid Pioneer-30R77 under $50 \times 20 \mathrm{~cm}^{2}$ planting density with soil test crop response (STCR) 
based nutrient management is recommended for achieving higher yield and economic benefit of maize during kharif season in West Bengal, India.

\section{ACKNOWLEDGMENT}

$\mathrm{T}$ he authors are grateful to ICAR-Indian Institute of Maize Research, Ludhiana, India for the financial support under AICRP on Maize to conduct the research work.

\section{REFERENCES}

Al-Naggar, A.M.M., Shabana, R., Ibrahim, A.A., 2021. Effect of plant density, genotype and their interaction on agronomical, physiological and yield traits of maize (Zea mays L.). Plant Cell Biotechnology and Molecular 22(49-50), 106-121.

Battaglia, M., Lee, C., Tomason, W., Mullekom, J.V., 2019. Effects of corn row width and defoliation timing and intensity on canopy light interception. Crop Science 59(4), 1718-1731.

Bernhard, B.J., Below, F.E., 2020. Plant population and row spacing effect on corn: Plant growth, Phenology and grain yield. Agronomy Journal 112, 2456-2465.

Biswas, S., Saha, A., Debnath, S., Chatterjee, S., 2020. Performance of maize genotypes in kharif under varying planting density and nutrient levels in new alluvial zone of West Bengal. Multilogic in Science IX ( XXXII), 477-478.

Chen, G., Cao, H., Liang, J., Ma, W., Guo, L., Zhang, S., Jiang, R., Zhang, H., Goulding, K.W.T., Zhang, F., 2018. Factors affecting nitrogen use efficiency and grain yield of summer maize on smallholder farms in the North China Plain. Sustainability 10, 363.

Coelho, A.E., Sangoi, L., Junior, A.A.B., Fioreze, S.L., Berghetti, J., Kuneski, H.F., Leolato, L.S., Junior, M.C.M., 2020. Growth patterns and yield of maize (Zea mays) hybrids as affected by nitrogen rate and sowing date in southern Brazil. Crop and Pasture Science 71(12), 976-986.

Davidson, E.A., Suddick, E.C., Rice, C.W., Prokopy, L.S., 2015. More food, low pollution (Mo Fo Lo Po): A grand challenge for the 21st century. Journal of Environmental Quality 44, 305-311.

Du, X., Wang, Z., Lei, W., 2021. Increased planting density combined with reduced nitrogen rate to achieve high yield in maize. Scientific Reports 11,358. https://doi. org/10.1038/s41598-020-79633-z.

Hargilas, Singh, A.K., Jat, S.L., Rokadia, P.K., Kumar, A., 2017. Response of maize (Zea mays) hybrids to nutrient management practices for enhancing productivity and profitability under sub-humid condition of Southern Rajasthan. Indian Journal of
Agronomy 62(3), 326-331.

Huang, M., Chen, J., Cao, F., Zou, Y., 2018. Increased hill density can compensate for yield loss from reduced nitrogen input in machine transplanted doublecropped rice. Field Crops Research 221, 333-338.

Joshi, E., Vyas, A.K., Dass, A., Dhar, A., 2016. Nutrient omission effects on yield, water productivity and profitability of maize (Zea mays). Indian Journal of Agronomy 61(2), 204-209.

Joshi, N., Chandrasekar, C.P., 2017. Precision nutrient management in maize (Zea mays L.) under northern transition zone of Karnataka. Journal of Farm Sciences 30(3), 343-348.

Ke, F., Ma, X., 2021. Responses of maize hybrids with contrasting maturity to planting date in Northeast China. Scientific Report 11, 15776. https://doi. org/10.1038/s41598-021-95328-5.

Khedwal, R.S., Yadav, D.B., Hooda, V.S., 2018. Crop residue management in no-till maize: Influence the growth, yield and economics of kharif maize (Zea mays L.). Forage Research 44(2), 90-95.

Kumar, B., Guleria, S.K., Khanorkar, S.M., Dubey, R.B., Patel, J.M., Kumar, V., Parihar, C.M., Jat, S.L., Singh, V., Yathish, K.R., Das, A., Sekhar, J.C., Bhati, P., Kaur, H., Kumar, M., Singh, A.K., Varghese, E., Yadav, O.P., 2016. Selection indices to identify maize (Zea mays L.) hybrids adapted under drought stress and normal ecologies in tropical climate. Crop and Pasture Science 67, 1087-1095.

Naik, A.A., Reddy, M.S., Babu, P.V.R., Kavitha, P., 2019. Effect of plant density and nitrogen management on growth, yield and economics of sweet corn (Zea mays var. Saccharata). The Pharma Innovation Journal 8(6), 839-842.

Neha, J., Chandrashekar, C.P., 2018. Precision nutrient management in maize (Zea mays L.) under northern transition zone of Karnataka. Journal of Farm Sciences 30(3), 343-348.

Parihar, C.M., Jat, S.L., Singh, A.K., Ghosh, A., Rathore, N.S., Kumar, B., Pradhan, S., Majumdar, K., Satyanarayana, T., Jat, M.L., Saharawat, Y.S., Kuri, B.R., Saveipune, D., 2017. Effects of precision conservation agriculture in a maize-wheat-mungbean rotation on crop yield, water-use and radiation conversion under a semiarid agro-ecosystem. Agricultural Water Management 192, 306-319.

Ranva, S., Singh, Y.V., Jain, N., Bana, R.C., Bana, R.S., Bajya, D.R., 2019. Effect of natural safe rock minerals on growth, yield and quality of rice (Oryza sativa) in rice-wheat cropping system. Indian Journal of Agricultural Sciences 89(9),1529-1535.

Ray, K., Banerjee, H., Bhattacharyya, K., Dutta, S., 2018. 
Site Specific nutrient management for maize hybrids in an inteptisol of West Bengal, India. Experimental Agriculture 54(6), 874-887.

Shabnam, S., Sharma, K., Rana, R.S., Sankhyan, N.K., 2017. Effect of STCR based nutrient management on yield, nutrient uptake and profitability of maize (Zea mays) in an acid Alfisol of North western Himalayas. Ecology. Environment and Conservation 23(4), 2275-2279.

Shafi, M., Bakht. J., Ali, S., 2012. Effect of planting density on phenology, growth and yield of maize (Zea mays L.). Pakistan Journal of Botany 44(2), 691-696.

Shi, D.Y., Li, Y.H., Zhang, J.W., Liu, P., 2016. Increased plant density and reduced $\mathrm{N}$ rate lead to more grain yield and higher resource utilization in summer maize. Journal of Integrative Agriculture 15, 2515-528.

Shiferaw, B., Prasanna, B., Hellin, J., Bänziger, M., 2011. Crops that feed the world 6. Past successes and future challenges to the role played by maize in global food security. Food Security 3, 307-327.

Shreenivas, B.V., Ravi, M.V., Latha, H.S., 2017. Effect of nutrient management approaches on maximizing productivity, nutrient uptake, soil fertility and economics of maize (Zea mays L.)-chickpea (Cicer arietinum L.) cropping sequence. An Asian Journal of soil science 12(1), 1-9.

Shyam, C.S., Rathore, S.S., Kapila, S., Singh, R.K., Padhan, S.R., Singh, V.K., 2021. Precision nutrient management in maize (Zea mays) for higher productivity and profitability. Indian Journal of Agricultural Sciences 91(6), 933-935.

Singh, V., Ramanjit, K., Singh, B., Singh, B., Kaur, A., 2016. Precision nutrient management: A review. Indian Journal of Fertilisers 12(11), 85-100.

Singh, M.V., 2016. Effect of planting density and nutrient management on performance of rabi hybrid maize. Annals of Plant and Soil Research 18(3), 275-279.

Singh, M.V., Kumar, N., Singh, B., Prakash, V., 2016. Productivity and profitability of rabi maize hybrids under nutrients management practices. Annals of Plant and Soil Research 18(1), 70-73.

Singh, M.V., Kumar, N., Srivastava, R.K., 2018. Effect of nutrient management on maize (Zea mays) hybrid in eastern zone of Uttar Pradesh. Annals of Plant and Soil Research 20(1), 99-102.

Singh, A.K., Jat, S.L., Parihar, C.M., Kumar, M., Singh, C.S., Hallikeri, S.S., Sreelatha, D., Manjulatha, G., Maha, D.M., 2020. Precision nutrient management for enhanced yield and profitability of maize (Zea mays). Indian Journal of Agricultural Sciences 90(5), 952-956.

Singh, M.V., Kumar, N., Srivastava, R.K., 2017. Effect of planting density and nutrient management on performance of kharif maize (Zea mays L.). Annals of Plant and Soil Science 19(2), 195-199.

Singh, M.V., Kumar, N., Srivastava, R.K., 2017. Effect of nitrogen and its scheduling on growth, yield and economics of rabi maize (Zea mays L). Annals of Plant and Soil Research 19(3), 307-310.

Singh, V.K., Gautam, P., Nanda, G., Dhaliwal, S.S., Pramanick, B., Meena, S.S., Walaa, F.A., Gaber , A., Sayed, S., Hossain, A., 2021. Soil test-based fertilizer application improves productivity, profitability and nutrient use efficiency of rice (Oryza sativa L.) under Direct Seeded Condition. Agronomy 11, 1756.

Wijewardana, C., Henry, W.B., Hock, M.W., Reddy, K.R., 2016. Growth and physiological trait variation among corn hybrids for cold tolerance. Canadian Journal of Plant Science 96(4), 1812-1819.

Yu, X., Zhang, Q., Gao, J., Wang, Z., Borjigin, Q., Hu, S., Zhang, B., Ma, D., 2019. Planting density tolerance of high-yielding maize and the mechanisms underlying yield improvement with subsoiling and increased planting density. Agronomy 9(370), 1-16.

Xu, C., Huang, S., Tian, B., Ren, J., Meng, Q., Wang, P., 2017. Manipulating planting density and nitrogen fertilizer application to improve yield and reduce environmental impact in Chinese maize production. Frontiers in Plant Science 8(1234), 1-11.

Yadav, O.P., Prasanna, B.M., Yadava, P., Jat, S.L., Kumar, D., Dhillon, B.S., Solanki, I.S., Sandhu, J.S., 2016. Doubling maize production of India by 2025 - Challenges and opportunities. Indian Journal Agricultural Sciences 86(4), 427-434.

Yao, H., Zhang, Y., Yi, X., Zhang, X., Zhang, W., 2016. Cotton responds to different plant population densities by adjusting specific leaf area to optimize canopy photosynthetic use efficiency of light and nitrogen. Field Crops Research 188, 10-16.

Yong, T. W., Chen, P., Dong, Q., Du, Q. Yang, F., Wang, X. C., Liu, W.G., Yang, W.Y., 2018. Optimized nitrogen application methods to improve nitrogen use efficiency and nodule nitrogen fixation in a maize-soybean relay intercropping system. Journal of Integrative Agriculture 17, 664-676.

Zhai, L.C., Xie, R.Z., Ming, B., Li., S.K., Ma, D.L., 2018. Evaluation and analysis of intra-specific competition in maize: A case study on plant density experiment. Journal Integrative Agriculture 17, 2235-2244

Zhang, T., Wang, H., Quiliang, L, Luo, J., Linday, S., Zhang, J., Zhai, L., Wu, S., Zhang, J., Liu, X., Ren, T., Liu, H., 2018. Optimizing the nitrogen application rate for maize and wheat based on yield an environment on the Northern China Plain. Science of the Total Environment 618, 1173-1183. 